\title{
RACIALISING RELIGION \\ IN THE DEBATE ON RELIGIOUS FREEDOM IN MALAYSIA
}

\author{
Saskia Louise Shafer \\ Berlin Graduate School Muslim Cultures and Societies
}

\begin{abstract}
This article summarises the results of a media analysis conducted by the example of one of the country's biggest daily newspapers, the New Straits Times. With regard to the controversial religious freedom debate, it summarises what actors are involved in the discussion and how their positions are presented in the mainstream media. Several examples from articles show what strategies are employed in the discourse, such as the rhetoric of fear and crisis and the constant emphasis of racial and other supposedly separating categories. The close linkage of the categories 'ethnicity' and 'religion', which is manifested legally as well as politically, is perpetuated linguistically. Especially important in this context is the construction of a Muslim-Malay identity.
\end{abstract}

Keywords: religious freedom, media analysis, ethnicity, religion, muslim identity

\section{A. Introduction}

Despite the surprising election results of 2008, Malaysia remains a country with many obstacles to democratisation, irrespective of whether one understands democracy minimally as an electoral process or generally as people's power and participation. One major hindrance to consensus-building is the mindset brought about by a political system that is based on the categories of race $^{1}$ and religion. These two 
categories have at least since colonial rule played an important role in determining the individual citizen's identity. The government perpetuates the colonial categorisation of the Malaysian citizenry into official ethnic groups. Additionally to ethnic categorisation in birth certificate, ID cards of citizens classified as Muslim carry the word 'Islam'.

Malaysia, comprising a population of around 25 Million people, officially counts about $60 \%$ Muslims, the biggest minorities stated to be Buddhists and Christians. ${ }^{2}$ Despite the relatively small number of citizens, Malaysia is present on the international stage and known as a modern country with an impressive record of economic development. Thus, it is often seen as a possible role model for other predominantly Muslim states. Furthermore, the diversity of its citizenry is typical for post-colonial societies. The debates related to the country's multireligiousity range from the discussion on who is entitled to use the word 'Allah', to fights between families on the one side and the state on the other over how a deceased person whose religious affiliation is debated should be buried.

The significance of the religious categorisation has increased in recent years. Unlike his or her non-Muslim counterpart, a citizen born to parents who are categorised as Muslim will fall under shariah law when it comes to matters related to marriage, inheritance and personal morality. One can argue that equality before the law, an important factor of democracy, is not given. Additionally, observers testify growing communitarianism along religious lines. At the same time, the dominant component of the governing coalition, United Malays National Organisation (UMNO), and their main rival for votes of those classified as Malays, the Islamist opposition party Parti Islam SeMalaysia (PAS), compete in establishing their own respective version or brand of Islam. This 'holier-than-thou-race' has lead to an overall more conservative

${ }^{1}$ I explicitly distance myself from the categories of race and ethnicity in any other form than the discursive. Both the category of race and the category of ethnicity have no other valid foundation than their discursive construction. They are thus used only in this regard in this paper.

${ }^{2}$ Department of Statistics Malaysia, Population Distribution and Basis Demographic Characteristics Report - Population and Housing Census 2000 (Putrajaya, 2001). 
character of the public discussion on Islam.

The religious identity marker has become so intertwined with the racial one that the two are often used synonymously and it could be argued that the religious marker is slowly replacing the ethnical. The following paper shows by means of a discourse analysis of the New Straits Times, one of the nation's leading English language newspapers how the categories of race/ethnicity and religion are interlinked and the old barriers linguistically perpetuated in daily media coverage.

\section{Malaysia's Political System}

Malaysia is a constitutional monarchy. The prime minister is the head of government within a multi-party system. Executive power is with the government, while federal legislative power lies with both the government and the two parliamentary chambers.

Although one finds the typical institutions of a liberal democracy based on the British system, most scholars of political studies agree in calling Malaysia a semi-democracy or a (semi-) autocratic system. Political scientists Steven Levitsky and Lucan A. Way identify 'competitive authoritarianism' as “one particular type of 'hybrid' regime" and classify Malaysia as such. ${ }^{3}$

While the elections themselves are mainly free, they cannot be considered fair. ${ }^{4}$ They are only to a certain extent competitive and the oppositional parties are starkly disadvantaged. The constituencies are designed in UMNO's favour and various political freedoms, like freedom of speech, freedom of assembly and the right to demonstrate, are restricted. Since the formation of Malaysia in 1963, politics have been dominated by UMNO. The party constitutes the major component of the ruling Barisan National (BN; National Front) coalition which also includes the Malaysian Chinese Association (MCA) and the Malaysian Indian Congress (MIC).

3 Steven Levitsky and Lucan A. Way, "The Rise of Competetive Authoritarianism", Journal of Democracy, 13 (2002), p. 52.

4 see for instance Harold Crouch, Government and Society in Malaysia (St Leonards, New South Wales: Allen and Unwin, 1996) p. 75. 


\section{Malaysia's Media}

Although freedom of speech and press freedom are enshrined in Article 10 of the constitution, Malaysian media face restrictions on several levels. Most TV and radio channels are indirectly state-owned or -controlled, as is a large percentage of the print media. The media additionally face restrictions through the obligation of annually getting their publishing licence renewed. While the importance of the media as an arena of democratic contestation is undisputed for Malaysia, the emergence of widespread independent journalism is still in its beginning and relies very much on online sources.

While the internet press is of increasing importance and critical coverage is believed to have played an important role in leading to UMNO's severe loss in the 2008 elections, ${ }^{5}$ the printing press does react to this development. Newspapers like the English language New Straits Times and The Star begin to give space to critical voices and often react to precedent reports by alternative media.

Accessing it on the level of English language mainstream media sheds light on 'UMNO-speak' and thus on the institutional power that has exercised social engineering since the existence of Malaysia. Keeping in mind Foucault's notion of power, we emanate from the idea that this power is to a large extent realised through language and discourse.

\section{The Linkage of Race/Etbnicity and Religion}

As aforementioned, the government has continued the colonial categorisation of the population into four groups: Bumiputera (mainly Malays), ${ }^{6}$ Chinese, Indians and Others. Malays/Bumiputera have been secured a special position in the constitution (Article 153(2) and have been granted numerous privileges since the introduction of the

5 see Hang Wu Tang, "Let a Hundred Flowers Bloom: Digital Speech in Malaysia", Asian Journal of Comparative Law, 1(2007); Andreas Ufen, "Politischer Neubeginn in Malaysia: Die Parlamentswahlen vom März 2008”, GIGA-Focus, 4 (2008), p. 4.

${ }^{6}$ Bumiputera means literally 'sons/children of the soil' and includes Malays as well as other 'native ethnic groups' in Sabah and Sarawak. The definition has grown to incorporate smaller minorities, yet it largely comprises those identified as Malay. 
affirmative action program New Economic Policy (NEP) in 1971, as for instance easier access to education and loans. Although the NEP was officially terminated in 1991, many privileges remain in existence until today. The Malay/Bumiputera group is presented and perceived as more homogeneous than the others, not least due to the consequent identity engineering by the government, of which the linkage of ethnicity and religion is one manoeuvre.

The linkage of religion and ethnicity is not only perpetuated on a textual level, but also legally. A Malay is constitutionally defined as someone who speaks the Malay language, practices Malay customs and professes the religion of Islam (Art.160). The applicability of Syariah is therefore directly linked to being categorised as Malay.

A conversion to Islam from another religion was traditionally understood and described as 'masuk Melayu' or becoming Malay or entering Malayness. ${ }^{7}$ A Chinese convert to Islam faces the difficulty of not being fully accepted as a Muslim by fellow Muslims who are predominantly Malay. ${ }^{8}$ This 'knot' of ethnicity and religion in this institutionalised form is a special characteristic of the Malaysian case.

Notwithstanding the difference between the two, the connection between Islam and Malay identity is of growing importance, as the initially race-based politics are increasingly religion-based. ${ }^{9}$ It is for instance striking that in the media, Islam is not nearly as often discussed in religious contexts as in political. ${ }^{10}$ The shift from emphasis of ethnicity to that of religion especially becomes evident in the differentiation between Muslims and non-Muslims.

${ }^{7}$ Judith Nagata, The Chinese Muslims of Malaysia: New Malays or New Associates? A Problem of Religion and Ethnicity: The Past in Southeast Asia's Present, Ottawa: Canadian Council for Southeast Asian Studies, 1978), p. 108.

${ }^{8}$ Joy Y. Lam, Religious Conversion and Reconstruction of Identities: The Case of Chinese Muslim Converts in Malaysia, Hong Kong: Southeast Asia Research Centre, City University of Hong Kong, 2004), p. 6.

9 Farish A. Noor, "Race and Islam", Daily Times, Lahore, 2008.

${ }^{10}$ This hypothesis was verified during a quantitative discourse analysis in a seminar held by Eva Streifeneder and Frederik Holst at Humboldt University in 2006/ 2007. 


\section{Discourse Analysis: Material and Processing}

For the purposes of this paper, the electronic archives of the New Straits Times from 2001 until July 2007 were scanned. The date for the beginning of the analysis is based on Mahathir's significant declaration in October 2001 that Malaysia is an Islamic state. The analysed time frame ends with Najib's confirmation of the declaration and herewith follows Clive Kessler's interpretation of an accomplished change of UMNO to a party that offer no alternative to PAS, as explained above. ${ }^{11}$

Several key words were used and after a first scan of all titles and headlines the most relevant articles were chosen. ${ }^{12}$

Those articles filtered out mainly regard foreign affairs. Although these are of course indirectly related to the portrayal of the national situation, they are not as interesting as the articles from the section on national politics. Some significant reports about foreign issues have remained in the pool.

The key words used were "religious freedom", "apostasy", "Article 11", "Islamic State" and the names of individuals involved in high profile cases regarding religious freedom, such as "Lina Joy", "Shamala", "Moorthy", "Wong Ah Kiu", "Revathi". These keywords cover the large majority of, if not all articles related to the topic of religious freedom.

They altogether brought about around 600 articles of which all headlines and most first paragraphs were read to filter about 120 relevant articles. The articles identified as significant were read and structurally ${ }^{13}$ analysed in full.

${ }^{11}$ Clive S. Kessler, Islam, the State \&o Desecularisation: The Islamist Trajectory During the Badawi Years: Sharing the Nation (Petaling Jaya: Strategic Information and Research Development Centre, 2008).

${ }^{12}$ It is an admitted methodological weakness of Jäger's procedure that the criteria for this selection are not entirely clear. After an overview scanning and rough analyses, the researcher chooses representative articles according to his or her evaluation; see Siegfried Jäger (ed.), Wie kritisch ist die Kritische Diskursanalyse? (Münster: UnrastVerlag, 2008), p. 28.

${ }^{13}$ The term "structural analysis" describes a rough analysis, including collective symbols, content and the like. See Ibid., p. 172, footnote 178. 


\section{Actors and Strategies in the Debate on Religious Freedom}

For a more detailed understanding of the discursive setting, it is useful to look at political scientist Claudia Derichs' analysis of popular Islamic discourse,${ }^{14}$ where she identifies five groups of actors as examples and representatives of the plurality of Malaysia's discourse setting. She names (1) the leaders and members of PAS and the conservative Muslim organisation Persatuan Ulama Malaysia, (2) the liberal women's rights organisation Sisters in Islam, (3) Islamic NGOs and movements like ABIM, (4) Islamist/extremist NGOs and movements, and finally (5) the "government camp". ${ }^{15}$

Derichs borrows a typology of discourse strategies where she categorises discourse strategies into five clusters of characteristics: ${ }^{16}$

1) The preserving strategy is status quo-oriented and frequently utilised by the existing powers.

2) The rectifying strategy is status quo-oriented, but in a more defensive manner, often trying to rescue a damaged reputation.

3) The constructive strategy, change-oriented and reform-seeking, goes beyond criticisms of the status quo and suggests concepts and ideas. An example is the above mentioned monogamy campaign by SIS. Rather than voicing transformatory demands (see 4), the campaign aimed at raising awareness of existing rights and possibilities among Muslim women.

4) The change-oriented transformation attempts are often hard to distinguish from the constructive argumentation. Generally, they are stronger than the former and are often sought by victims of certain circumstances and conditions. For instance, questioning the codified Malay rights would be such a transformatory demand, usually met with severe consequences for those who dare to speak it out. Thus, Derichs points out, this strategy seldom succeeds under authoritarian systems.

${ }^{14}$ Claudia Derichs, "Form Follows Function? Popular Islamic Discourse in Malaysia", in M. B. Mathias Hildebrandt (ed.), Unfriedliche Religionen (Wiesbaden: VS Verlag für Sozialwissenschaften, 2005), pp. 122-128.

${ }^{15}$ Ibid. 
5) The most radical strategy, the destructive one, is almost never employed by critics of the government, but sometimes by the government itself. Derichs refers to the intended destruction of Anwar Ibrahim's reputation by questioning his Islamic credentials through the accusations of sodomy and also cites the discussion in 2003 on closing all religious schools because the teachers were allegedly PAS-leaning.

Since this analysis focuses on the New Straits Times and thus on the UMNO-dominated discourse, most of the results can be sorted under Derichs' first two status quo-oriented strategic categories, namely the preserving and the rectifying strategy. It has to be kept in mind that all discourse strings and levels are interconnected and thus certain strategies, especially those employed by the government, are reactions to others, e.g. to criticisms from the opposition.

During this analysis, twelve discursive strategies ${ }^{17}$ were identified.

Such strategies include the frequent use of racial categories, their linkage to the category of religion, the rhetoric of crisis and fear as well as the repetitive reminding of the riots in 1969. The rhetoric of division is continued in the calling for interfaith dialogue which is not supported by institutional changes, as shown by means of the example of the article on Najib's appeal to hold more interfaith dialogues. Rhetoric of division is in addition to the internal division used to perpetuate the old divide between Asia and 'the West'. Some headlines are strongly judgemental and strengthen doubts about the already questionable objectivity of the coverage.

It is remarkable how often political leaders and reporters refer to the constitution. Furthermore, certain subjects are monopolised and some groups are asked not to comment on them, while the political decision makers claim openness and directness regarding sensitive issues for them. The language used in the analysed articles perpetuates the idea of 'once a Muslim, always a Muslim'. Finally, it becomes evident that those who influence the newspaper aim at monopolising the right to interpretation of Islam.

${ }^{17}$ Ibid., pp. $128-130$. 
The most important strategy is the constant perpetuation of division and the threat of further division that could in the worst case escalate into violence. There are several dimensions to this threat, the most significant being the division within the Malaysian society along so-called racial or ethnic lines on one side and, often synonymously used, religious lines on the other side.

The racial division is perpetuated in many aspects of daily life and daily language as well as being a continuous theme in the media. The frequent use of racial categories is increasingly complemented by the synonymous use of religious categorisation. Very often, "race and religion" and the formulation "multi-racial and multi-religious" are mentioned together as if an inseparable tandem and raise the impression that the lines run congruently.

"They (Christmas carols, SLS) are certainly not out of place in an Open House, which Rais correctly describes as 'a joyous occasion where people of all races and religions can get together and partake of the celebration." ${ }^{\prime 18}$

This formulation unnecessarily includes the word 'race' and thereby suggests that there are 'racial' festivities, or that festivities are likely to be celebrated only with people of your own 'race'. The religious festivals of course claim universality and as a matter of course are neither race-bound nor bound to any other political or social community other than the religious.

Several other examples show this synonymous use:

"The Prime Minister said religious tolerance among the various races was vital in preserving the country's peace and harmony". ${ }^{19}$

Here, rather than saying 'among the various religious communities', the word 'race' is utilised to suggest the congruence already mentioned.

${ }^{18}$ The term strategies is used because " $(. .$.$) contributions to a public discourse$ do not appear without a certain idea, concept or objective in the mind of the contributors. In most cases, discourse actors would like to see their argument become accepted by a broader audience or even generate some change within the thinking of other influential actors. The intention of a discourse actor lies in the provocation of thought"; Ibid., p. 121.

${ }^{19}$ Joyous Sounds of Christmas, 21.12.2004. 
Another pattern repeatedly observed is the preceding mentioning of 'non-Muslims' and then referring to the Chinese:

"He said Pas" stand on the matter was also causing fear among nonMuslim communities. Ong said the MCA and Chinese (emphasis mine, SLS) accepted and respected Islam as the official religion, but, this was not applicable to Pas' plans." ${ }^{20}$

"Malaysian Chinese have been assured that they will not lose their rights and privileges despite the recent statement by Prime Minister Datuk Seri Dr. Mahathir Mohamad that the country is an Islamic state."21

Another similar example:

"Non-Muslim parties in the country today welcomed Prime Minister Datuk Seri Abdullah Ahmad Badawi's assurance yesterday that Islamisation will not hurt non-Muslims. MCA Youth secretary-general Liow Tiong Lai (emphasis mine, SLS) said non-Muslims should regard Islam 'holistically' as a dynamic and progressive religion that would take the country forward." 22

“[DAP leaders] felt they suffered as a consequence of Pas' insistence on its brand of an Islamic state for Malaysia, which pushed Chinese (emphasis mine, SLS) voters towards MCA and Gerakan." ${ }^{23}$

In all cases, an antagonism between Islam (and thus Muslims) and Chinese is built, despite the fact that Islam as a universal religion is as a matter of course not bound by 'race' and despite the existence of large Muslim communities in China and that of Muslim Malaysians of Chinese origin, including converts as well as members of families who have for hundreds of years been Muslim.

The same pattern is used to identify Malays with Muslims:

"The survey, conducted in late December, also indicates that while nonMuslims are generally comfortable with the level of Islamisation in Malaysia, the Malays (emphasis mine, SLS) want more". ${ }^{24}$

\footnotetext{
${ }^{20}$ PM: Religious Tolerance is vital, 14.05.2001.

${ }^{21}$ MCA against PAS' Islamic state plan, 16.07.2001.

${ }^{22}$ Ling: Our rights are assured, 21.10.2001.

${ }^{23}$ Non-Muslim parties hail PM's assurance, 25.02.2004.

${ }^{24}$ See more results for PKR playing both ends against the middle, 23.06.2007.
} 
"Q: What about certain ongoing issues which are race-sensitive?

A: (For instance) when one wants to leave Islam, it raises a lot of questions. This is a new experience to us." ${ }^{25}$

“(...) 500 people who gathered to disrupt the Article 11 forum here last year shouted Islamic slogans which caused anxiety to other races." ${ }^{\prime 26}$

This connection of race and religion is not only obvious in the cited examples, but also in an article on the Lina Joy judgement: "On April 23, 2001, the court dismissed her application on the grounds that the issue should be decided by the syariah court. It also held that as a Malay and a Muslim, she could not convert." ${ }^{27}$ The racial and religious categories are completely self-evidently used together, demonstrating their indivisibility in state-centred Malaysian understanding.

Besides the constant language of separation, the rhetoric of crisis and fear is important. The government portrays itself as the preserver of peace and stability without which not only the different 'ethnic' groups would attack each other, but without which especially those classified as Malay would lose their position.

Examples:

Headline: "CM: 'Pas' aim to set up Islamic state will divide the country". ${ }^{28}$

“'PM: Religious tolerance vital': “The Prime Minister said religious tolerance among the various races (emphasis mine, SLS) was vital in preserving the country's peace and harmony. The world, he said, had seen how religious intolerance could cause infighting and chaos among followers of different faiths or denominations. (...) Malaysians should be grateful that they could lead such harmonious and peaceful lives despite living in a multi-religious society. Unlike some other countries, he said, there was freedom to practise one's own religion in this country. 'We see places of worship everywhere in this country. It will be very difficult to quell tense situations once there is (emphases mine, SLS) distrust and

\footnotetext{
${ }^{25}$ Malays trust ulama to tell the truth more than anyone else, 29.02.2004.

${ }^{26}$ Behind closed doors, sometimes, 13.05.2007.

${ }^{27}$ Protesters caused anxiety to other races, 07.08.2007.

${ }^{28}$ Lina must go to syariah court, 31.05.2007.
} 
disrespect among one another as a result of religious intolerance". ${ }^{29}$

Here, the usage of future and present tense rather than the adequate subjunctive suggests the proximity of danger.

The constant reminder of the riots in May 1969 is employed in the following interview too:

"RACIAL (sic) unity in the country has come a long way since May 13, 1969. Though the foundations are strong, more can be done to strengthen it. PATRICK SENNYAH (sic) speaks to Datuk Dr Maximus Ongkili, the Minister in the Prime Minister's Department in charge of national unity, on the issue.

Q: How would you describe racial unity now?

A: I have been in this job for the last three years. (...) In fact, the relationship among the Malays, Chinese and Indians has never been better. People are more conscious now and aware of the importance of racial tolerance. Nobody wants a repeat of May 13."

The fact that a minister is in charge of national unity is noticeable. Furthermore, the word 'race' appears three times in these nine lines, complemented by the usual categories. The usual Sword of Damocles, the riots of 13 May 1969, is used to demonstrate the government's success in cooling down the tensions since. The government's role, here represented by the interviewed Minister, is emphasised by highlighting the five visits of the Minister in Kampung Medan, a district in Kuala Lumpur that saw violent outbreaks in 2001.

Further:

"I believe in Malaysia, unity strongly exists. What we need to work on is the integration part. Overall, the situation is fine. The police don't get many race-based complaints, just about 300 per year.

Q: Could you elaborate on these race-based complaints?

A: Sometimes it is over a woman, like the last such complaint in Cheras two months ago. ${ }^{30}$

\footnotetext{
${ }^{29} 18.02 .2001$.

${ }^{30} 14.05 .2001$.
} 
The topic of 'race' is very much in the foreground. In what way a dispute over personal affairs can count as a 'race-based complaint' remains unclear.

Another vital tactic is the calling for interfaith dialogue while at the same time not supporting it organisationally. It can also be argued that the call for dialogue as such is already divisive, because it perpetuates the impression of divided groups, which may not be as divided as rhetorically portrayed. ${ }^{31}$

Example: The article titled "Najib: Hold more Interfaith Dialogues" reads:

"Interfaith and inter-culture dialogues should be encouraged so that the people are familiar with and appreciate universal values, said Deputy Prime Minister Datuk Seri Najib Razak. He said tension between the Christian and Muslim civilisations could be eased if there were more such dialogues". 32

In this example, the dichotomy between Muslim and Christian 'civilisations' is employed.

Another example:

"Because inter-religious distrust and suspicion can so easily exacerbate communal feelings, it is incumbent upon Muslim and non-Muslim communities to harness their moral and intellectual energies to create an atmosphere that is more conducive to inter-religious understanding and harmony". ${ }^{33}$

Interestingly, this comment is written by Chandra Muzaffar, a well known public intellectual in Malaysia who is a human rights activist and very involved in several liberal civil society organisations.

Other lines of division regard not the internal division, but the global rhetoric of a division between 'orient' and 'occident' or between Malaysia and its neighbours.

"Today, the concept of democracy is still being contested and negotiated by a number of different social actors and marginalised

\footnotetext{
${ }^{31}$ Behind closed doors, sometimes, 13.05.2007.

${ }^{32}$ see Olivier Olivier Roy, "Le découplage de la religion et de la culture: une exception musulmane?”, Esprit, 333 (2007), p. 242.

${ }^{33}$ Najib: Hold more Interfaith Dialogues, 27.12.2004.
} 
groupings in the West. This is why even religious minorities, like Muslim migrants in the West, continue to speak the language of democracy when pushing for their collective rights". ${ }^{34}$

An Interview with the already mentioned Datuk Dr Maximus Ongkili, minister in charge of national unity:

"Worse, there is a high concentration of illegal immigrants living in these areas. Many of these illegals look like Malaysians and sometimes when they misbehave, we think it is actually the work of one of our own people."

Despite Mahathir's image as an outspoken critic of 'the West', the internal division is much more important within Malaysian politics. The discourse on migration is heavily loaded with prejudices and judgements in Malaysian media, and the distinction from the neighbouring countries is one instrument to boost national identity. At the same time, through this tactic the Malaysian Malays are distinguished from Indonesian and Philippine Malays. This helps those in power to screen them off from the influence of their neighbours who sometimes share the Malay language and traditions, but are Christians.

Also noticeable is the strongly judgemental character of some headlines, such as in this article:

"Indefensible behaviour" (08.06.2005) as headline for an article describing how "no syariah (sic!) lawyer in Terengganu is apparently prepared to defend the 45 people being charged in the Syariah High Court for not complying with a State fatwa which declared the teachings of Ariffin Mohammad, aka Ayah Pin, to be deviant."

Interesting is also the frequent reference to the constitution. While liberal NGOs and intellectuals refer to the constitution to criticise the government, members of the government often refer to it as well and naturally find higher reportage of their version and interpretation in the mainstream media:

"The MCA is against any attempt by Pas to set up an Islamic State if it comes to power, party vice-president Datuk Seri Ong Ka Ting said today. He said the country's constitution, which allows freedom of

${ }^{34}$ Tackling inter-religious issues (comment), 31.12.2005. 
worship for all Malaysians, would be compromised and threatened should Pas rule the country." 35

"Nothing is going to change because the Federal Constitution will not be amended. We can continue to practise other religions in peace as guaranteed by the Constitution". ${ }^{36}$

"Religious freedom a way of life: 'Although Islam is recognised as the official religion in the Constitution, the liberty to practise other religions is constitutionally guaranteed as well'. ${ }^{37}$

This latter formulation implies that the official character of Islam was the constitution's main point and the religious freedom an appendage, while most sources make it clear that it was intended the other way round.

Another way of monopolising the sovereignty of interpretation for controversial matters is the request for certain groups not to engage with the respective subjects.

Example: "Bar Council told not to interfere in Islamic laws". 38

The government, through its media influence, claims openness about sensitive issues for itself:

"Some of the most contentious topics in Malaysia were discussed when 51 members of the National Unity Advisory Panel met today" 39

With such a statement, the government re-emphasises its role as an indispensable moderator in an immature environment. The usage of the phrase 'sensitive issues' in the headline also perpetuates the exact sensitivity of these topics.

Regarding the coverage of the conversion cases, it is interesting how language reflects the very idea of being born a Muslim and staying one:

"Joy, who claims she has converted to Christianity, is seeking to have the word 'Islam' deleted from her identity card'. ${ }^{40}$

\footnotetext{
${ }^{35}$ Give democracy a chance to prove itself, 03.03.2001.

${ }^{36}$ MCA against PAS' Islamic state plan, 16.07.2001.

${ }^{37}$ DPM: Umno-Pas talks unnecessary, 10.07.2001.

${ }^{38}$ Religious freedom a way of life, 22.12.2003.

${ }^{39}$ Headline 01.03.2002.

${ }^{40}$ Frank discussions on sensitive issues; Denial of right an injustice, 29.06.2006.
} 
While Lina Joy has been stating for many years now that she is not a Muslim, the newspaper still refers to her as such. Her conversion is occasionally portrayed as suspicious, as demonstrated here.

Due to efforts to monopolise the interpretation of Islam, formulations like the following example are frequent. The question is extracted from an interview with Mufti Dr Mohd Asri Zainul Abidin: "Why is there a difficult relationship between Muslims and nonMuslims? Is it because Islam has been misunderstood by others?" 42 This suggestive question not only emanates from a 'difficult relationship' in a biased way, but it also proposes that there are understandings of Islam that are right and wrong. Always underlying any discussion regarding Islam is the competition between PAS and $\mathrm{UMNO}$, thus it can be assumed that this questioning claims the right understanding for UMNO.

Important is also the way in which the blockages of the forums organised by the Article 11 coalition in 2006 were portrayed. Although a condemning comment of a government representative is mentioned in it, the following sampled interview with one of the protestors carries a suggestive judgemental title, 'We feel they have a hidden agenda', and gives a remarkable amount of space to a very conservative view on the discussion. The reproduction of large parts of the interview is due to its pertinence for illustrating common lines of argumentations. “(...) Mohd Azmi Abdul Hamid, one of those behind the protest, feels the civil society group has a hidden agenda.

He feels the Muslim community cannot accept any kind of pressure by Article 11 on the Government, especially if it involves a challenge to Islamic law. (...)

Q: Why did Badai demonstrate against the forum?

A: This forum is being seen by Muslims as a challenge to Syariah. They want to liberalise it in a way that conforms to Western values.

We cannot allow this. (...)

Q: Why has your movement not raised its views at the forums?

${ }^{42}$ Pas Youth following keenly, 04.07.2006. 
A: (...) Muslims cannot accept any kind of pressure that this forum is placing on the Government. (...)

Q: But Muslims were among panelists at the forum?

A: Unfortunately, other Muslims do not see them as representative of the community. They have their own secular, liberal, understanding of Islam. They want Syariah to be placed along with universal values and are in favour of a secular society in a secular state.

Because they are not representing the Muslim community, they are actually representing a secular minority group. We feel that what they stand for is their own perception of Islam.

They want Islam to be just a private matter and that Syariah law should only be used in handling private matters. They do not represent the community or what Islam stands for in this country. (...)

We feel they have a hidden agenda' ${ }^{43}$

It is remarkable how in this interview, the representative of Badai claims to speak for the whole Muslim community. This claim, constituting a major thread throughout the text, is supported by the summarising paragraph in the beginning of the article, where the author speaks about "the Muslim community" and thus does not question the interviewee's representative ambitions.

Besides exclusive formulations, the interviewee explicitly states that "other Muslims do not see them (the Muslim panellists at the forum, SLS) as representative of the community". Furthermore: "Because they are not representing the Muslim community, they are actually representing a secular minority group" and "They do not represent the community or what Islam stands for in this country". These formulations create a dichotomy between secularists and Muslims that remain unchallenged by the interviewer. Additionally, the Badai-representative's answers suggest a certain brand of Malaysian Islam and touches upon the old accusation of infiltration of Western values'.

\footnotetext{
${ }^{43}$ Countering the scary view of Islam, 10.12.2006
} 
The fact that this interview is given so much space and, despite some contrary opinions, remains large unchallenged in the overall coverage, suggests that this attitude may not be too far from what the government's own position.

\section{Conclusion}

The examples have illustrated different discursive strategies, differing in frequency and importance. A major strategy is the obvious perpetuation of the linkage of religion and ethnicity.

The identified discursive strategies, consciously or unconsciously employed, can be categorised according to their respective functions. One major function of the rhetoric of division is the old principle of divide and rule. Just as the colonial masters had divided their colonial subjects, often along racial criteria, the Malaysian power elite continued this scheme not only in the administrative procedures, but also in the daily language.

Part of this rhetoric of division is the frequent use of racial categories, especially in contexts where a person's race does not matter, for instance in the text sample regarding the religious festivities.

Striking is the linguistic dimension of the shift of the division line from Malays vs. non-Malays to Muslims vs. non-Muslims. This shift is evident in the equation of Malays and Muslims, for instance by contrasting the latter category to those classified as Chinese.

Part of the divisive speech is also the rhetoric of crisis and fear, including the frequent reminders of the riots in 1969, which are without exception portrayed as 'racial riots'. These reminders are not only subtly integrated into the usual coverage, but the sampled interview shows the explicit addressing of the issue on the 13 May. This framing further stresses the importance of the date, which is part of the nation's collective memory anyways.

The divisive rhetoric is supported by calls for interfaith dialogue in the NST, as in the comment by Chandra Muzaffar. The very idea of dialogue is based on the idea that there are different camps. ${ }^{44}$

${ }^{44}$ NST 21.05.2006. 
In the example of the comment by Chandra Muzaffar, the rhetoric of division are not only employed by representatives of the government or political extremists. He speaks of 'Muslim and nonMuslim communities', linguistically fuelling the tense atmosphere of increasing communitarianism along religious lines. This formulation is similar to the comparison of building bridges between cultures: For the necessity of a bridge, there has to be a gap in the first place, which is confirmed and perpetuated by calls for bridges or dialogues.

This is of course not only valid for the ever cited example of 'Islam and the West', but also for any similar context, in this case the illustrated inner-Malaysian discussion.

Whether Chandra Muzaffar used this formulation consciously for lack of space of an alternative phrasing or whether he used it unconsciously and out of good intentions remains unclear, but this is not so important for the analysis as the fact that not only those spokespersons close to the government utilise such divisive rhetoric, but also those who are usually seen as liberals.

This shows how effective the rhetoric is and how important it is to read the lines, and in between the lines, closely.

Additionally, the supporters of the government frequently refer to the constitution and thereby seek to legitimate their actions. The claim of openness regarding so-called sensitive issues, as in the reported meeting of the National Unity Advisory Panel, is interesting as it contrasts with the factual restrictions on free speech and the detentions of journalists described earlier.

Finally, another major feature is the shift from the racial to the religious divide, which goes further than divide and rule, namely supporting UMNO's monopolisation of Islam. Not only portraying $\mathrm{UMNO}$ as the sole protectors of the nation, the shift from the stressing of Malayness to that of Islam or Muslimness brings about the fight for the sole right interpretation of Islam. By publishing calls of Muslim extremists for non-Muslims to stay out of the discussion on one hand, and by portraying PAS' approach as wrong on the other, the sole right for the interpretation of Islam is claimed for the group of 'non-extremist Muslims' that UMNO claims to represent. 
Given the editorial power of those close to the government, it is likely to assume that the featured interview with the Badairepresentative does reflect UMNO's stance to a certain extent. The argumentation line employed in this interview seems to fit into Derichs' fifth category, that of destructive strategies. The interviewee clearly tries to deprive the panellists of the forums in particular and secular Muslims in general, of their credibility to speak for Islam or as Muslims.

The discourse perspective on the debate has demonstrated the multiple facets of the debate on religious topics in Malaysia. The positions in debates vary to a large extent and the lines run neither so much between Muslims and non-Muslims, nor between the government and the opposition, but between secularists, or liberals, and conservatives.

To gain a full picture of the linguistic dimension of communitarianism, it would be necessary to analyse alternative media and the texts of NGOs, especially those of liberal background. Even without having done a similarly thorough analysis, it can be said that the equation of race and religion is widespread in Malaysian discourse. Similar examples to those shown here in detail can be found in the online newspaper Malaysiakini. Surprisingly, although to a lesser extent, this is also true for the discourse of liberal NGOs, who occasionally slip into similar formulations.

This shows that an analysis of the NST not only reveals the strategies of parts of the government or those close to them, but in fact suggests a general tendency in Malaysian discourse.

As mentioned in the introduction, scholars of democracy studies expect a well educated middle class to challenge any autocratic regime and are surprised to find the transformation process - or democratisation- in Malaysia to remain in stalemate. Malaysia's economic success is remarkable and following the modernisation theorists' assumptions, one would expect the educated middle class to support and accelerate democratisation. Instead, the Malaysian middle class is divided and movements like ABIM or the Al-Arqam movement do insist on certain aspects of what most political scientists see as democratic values, but reject others and loudly voice their demands for provisions contradicting democratic ideals. 
The Bertelsmann Transformation Index (BTI) praises Malaysia's political stability, its high degree of state development, the stability of institutions and the economy, as well as the absence of undemocratic veto powers. However, Malaysia is classified as a 'moderate autocracy' (gemäßigte Autokratie). The BTI locates Malaysia’s problems mainly in the political structure and the "dynamics driven by ethno-religious tensions". ${ }^{45}$ The "divisions" and "increasing tensions between the Muslim majority and non-Muslim minority" pose threats to the democracy, just as "corruption and fundamentalist Islam" 46 do to state institutions and the secular government. The report sees the persistence of key shortcomings, "particularly regarding the electoral process, free media, political representation, rule of law, the effective and efficient democratic institutions, and consensus-building". ${ }^{47}$ The incident of the conversion rumours, where thousands of protestors gathered at a church after the word was spread via SMS text message that hundreds of Muslim were about to be baptised and converted, is mentioned as a disturbing symptom of the increasing radicalism of certain Muslim groups, ${ }^{48}$ just as the emergence and good organisation of the secular NGOs is praised as a positive development.

The high-profile cases of Islamic burials of non-Muslims and conversion of minors are illustrated, but surprisingly no direct reference to limited equality before the law is made. Although here unmentioned, the deficits in legal egalitarianism are a significant hindrance to liberal democracy. ${ }^{49}$ Although scholars of democracy studies disagree on the importance of social equality for democracy, legal equality is largely without controversy. Especially the fact that Malaysia's allegedly shariah-inspired laws prove very discriminating towards women (see the publications of Sisters in Islam and the works of Norani Othman) suggests that equality before the law is not only threatened by individual cases as those described earlier, but that inequality indeed cuts through the whole system and is thus a structural problem.

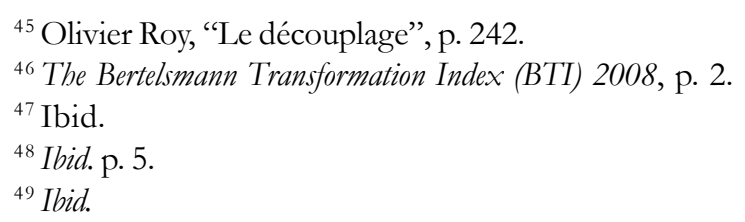


A major reason for pessimism among defenders and advocates of democracy and human rights is the increase of 'Muslim' symbols, institutions and structures, mostly simplified to 'Islamisation'. As the example of Sisters in Islam shows, political argumentation based on religion does not necessarily contradict democracy or human rights. Problematic is rather the character of the brand of Islam that is being promoted by influential parts of the government: an ethno-nationalist exclusive version, catering mainly to a limited group, in this case individuals classified as male, Muslim and Malay. Problematic is also the brand that parts of PAS, ABIM and Islamist groups like Jamaah Islah Malaysia try to sell, namely a literalist patriarchal version that denies any other ways of life their existence on an equal footing.

The term 'Islamisation' usually refers to the growing presence of symbols and ideas that are used and promoted by these groups. As explained, Clive Kessler sees the Malaysia since 2007 as one that is ruled by an "explicitly Islamist, Islamizing, shari"ah-promoting and antisecular party". ${ }^{50}$ Are these the last steps before the finalisation of an 'Islamic state'? As so often, the question is incomplete without a definition. Most Islamists would deny that Malaysia is anywhere near an Islamic state, they claim there has not been an Islamic state since the death of Ali, the last of the four Rightly Guided Caliphs. Their demands however, as outlined above, vary, and so do the definitions. A word that is often used to describe 'Islamist' regimes like Iran is theocracy, although it should accurately be 'rule of the clergy', rather than rule of God. A rule of the clergy would be an oligarchy and thus incompatible with the version of Islam that Muslim intellectuals like Abdullahi An Na-im promote. The role of Islam in Malaysia's historic and contemporary politics is controversial. While the problem that the term 'Islamisation' describes remains serious, the wording might be misleading. The analysis has shown that the real threat is a party that is too powerful and that uses its power to create a constant atmosphere of insecurity and division to legitimise itself.

${ }^{50}$ The German term ,Rechtsstaatlichkeit' or ,rule of law' is often used as an adjective for today's liberal democracies: 'rechtsstaaliche Demokratie'. This shows how closely connected the concepts of democracy and rule of law are. 
Racialising Religion in the Debate of Religious Freedom in Malaysia

One of its instruments, and one of increasing importance for various illustrated reasons, is religion, specifically Islam.

The growing communitarianism is attested by foreign ${ }^{51}$ as well as local scholars. ${ }^{52}$ One outcome and reason of this tendency is the language in which the various actors and individuals are referred to, often by those in power, but sometimes also by those who actually oppose the divisive results.

${ }^{51}$ Clive S. Kessler, Islam, the State, p. 70.

${ }^{52}$ For instance, The Bertelsmann Transformation Index (BTI) 2008.

${ }^{53}$ See Farish A. Noor, "Race and Islam". 


\section{BIBLIOGRAPHY}

Crouch, Harold, Government and Society in Malaysia, St Leonards, New South Wales: Allen and Unwin, 1996.

Department of Statistics Malaysia, Population Distribution and Basis Demographic Characteristics Report - Population and Housing Census 2000, Putrajaya, 2001.

Derichs, Claudia, "Form Follows Function? Popular Islamic Discourse in Malaysia", in M. B. Mathias Hildebrandt (ed.), Unfriedliche Religionen, Wiesbaden: VS Verlag für Sozialwissenschaften, 2005.

Hang Wu Tang, "Let a Hundred Flowers Bloom: Digital Speech in Malaysia", Asian Journal of Comparative Law, 1 (2007).

Jäger, Siegfried (ed.), Wie kritisch ist die Kritische Diskursanalyse?, Münster: Unrast-Verlag, 2008.

Kessler, Clive S., Islam, the State \& Desecularisation: The Islamist Trajectory During the Badawi Years: Sharing the Nation, Petaling Jaya: Strategic Information and Research Development Centre, 2008.

Lam, Joy Y., Religious Conversion and Reconstruction of Identities: The Case of Chinese Muslim Converts in Malaysia, Hong Kong: Southeast Asia Research Centre, City University of Hong Kong, 2004.

Levitsky, Steven and Lucan A. Way, "The Rise of Competetive Authoritarianism”, Journal of Democracy, 13 (2002): 51-65.

Nagata, Judith, The Chinese Muslims of Malaysia: New Malays or New Associates? A Problem of Religion and Ethnicity: The Past in Southeast Asia's Present, Ottawa: Canadian Council for Southeast Asian Studies, 1978.

Noor, Farish A., "Race and Islam", Daily Times, Lahore, 2008.

----, "The Business of Dialogue”, The Other Malaysia, 2008.

Othman, Norani, et al., Malaysia: Islamization, Muslim Politics and State Authoritarianism, Petaling Jaya: Sisters in Islam, 2005.

Roy, Olivier, "Le découplage de la religion et de la culture: une exception musulmane?", Esprit, 333 (2007): 242-252.

Ufen, Andreas, "Politischer Neubeginn in Malaysia: Die Parlamentswahlen vom März 2008”, GIGA-Focus, 4 (2008). 